\title{
NATURAL WEATHERING PERFORMANCE OF THREE FAST-GROWING EUCALYPT WOODS
}

\author{
Pedro Henrique Gonzalez de Cademartori ${ }^{1}$, André Luiz Missio ${ }^{2}$, \\ Bruno Dufau Mattos ${ }^{3}$, Darci Alberto Gatto ${ }^{2,4, A}$
}

\begin{abstract}
We investigated the effect of outdoor exposure on the wood surface from three fast-growing Brazilian eucalypts through color, wetting and thermal analyzes. Gympie messmate (Eucalyptus cloeziana), rose gum (Eucalyptus grandis) and blue gum (Eucalyptus saligna) woods were exposed outdoors in a subtropical region for 360 days. We performed three collections every 120 days. We investigated color changes of untreated and weathered woods through a spectrophotometer (CIE $L * a * b *$ system) and changes in macro compounds of wood through thermogravimetric analysis. In addition, the apparent contact angle and work of adhesion were evaluated using a goniometer. Outdoor exposure for 120 days provided significant increment in grayish of wood surface. Thermogravimetric curves of wood changed after the weathering, especially in the regions related to hemicelluloses and lignin thermal degradation. Outdoor exposure for 360 days converted hydrophilic wood surface into a very hydrophilic one, wherein occurrence of microcracks contributed to fully spreading of water droplets.
\end{abstract}

Keywords: Contact angle, Eucalyptus cloeziana, Eucalyptus grandis, Eucalyptus saligna, outdoor exposure, photodegradation, surface color.

\section{INTRODUCTION}

Wood is well accepted in building sector, furniture and industries for production of structural and non-structural products. Nevertheless, wood can be affected by extrinsic factors that limits its service life. Among these factors, the action of climatic agents - known as weathering - should be highlighted. These agents - especially, rain, sunlight and moisture - degrade the materials' surface and, consequently, reduce significantly its value-added, especially for aesthetic and non-structural uses.

Weathering of wood results in chemical, physical and anatomical changes. Loss of lightness, discoloration, cracking, checking and roughening of surfaces are some undesirable characteristics of wood after indoor or outdoor exposure. All these damages on the wood surface are related to chemical changes in the hemicelluloses, cellulose and lignin structures (Hon 2001). Lignin is the most susceptible component to weathering degradation (Feist and Hon 1984). Furthermore, changes of wood color occur due to the action of ultraviolet irradiation and fractions of the visible spectrum of solar irradiation, both in combination with oxidative agents, temperature and moisture (Rosu et al. 2010). Leaching of extractives from the surface of weathered woods reduces water repellence, while degradation of lignin results in a more hydrophilic surface (Rowell 2005).

\footnotetext{
Wood and Forestry Science Center (PPGEF), Federal University of Paraná, ZIP code 80210-170, Curitiba, Brazil.

${ }^{2}$ Forestry Engineering (PPGEF), Forest Products Laboratory, Centre for Rural Sciences, Federal University of Santa Maria, ZIP code 97105-900. Santa Maria, Brazil.

${ }^{3}$ Integrate Program in Engineering \& Materials Science (PIPE), Federal University of Paraná, Polytechnic Centre, ZIP code 81531-990, Curitiba, Brazil.

${ }^{4}$ College of Materials Engineering (PPGCEM), Federal University of Pelotas, ZIP code 96010-000, darcigatto@pq.cnpq.br, Pelotas, Brazil.

^ Corresponding Author: darcigatto@pq.cnpq.br

Received: 05.12.2014 Accepted: 24.06.2015
} 
Scientific studies have been conducted regarding the performance of native and exotic woods exposed to artificial weathering (Baysal et al. 2014, Valverde and Moya 2010, Baar and Gryc 2012, Grüll et al. 2014) and natural weathering (Rosu et al. 2010, Mattos et al. 2013, De Windt et al. 2014, Akhtari and Nicholas 2014). Thus, the investigation of woods from fast-growing species with high benefit in the market is important to improve their performance. In many situations, outdoor or indoor exposure of untreated wood occurs due to the unawareness of treatments for wood protection or due to the free choice by the consumer. Consequently, weathering deterioration is unavoidable, resulting in significant changes on the wood surface characteristics.

Rose gum (Eucalyptus grandis), blue gum (Eucalyptus saligna) and gympie messmate (Eucalyptus cloeziana) are species from Australia. In Brazil, these and other Eucalyptus species are exotic and well known for their fast growing. For example, average annual increment of Eucalyptus benthamii in Brazil is $48,37 \mathrm{~m}^{3} \mathrm{ha}^{-1} \mathrm{yr}^{-1}$ (Missio et al. 2014). Therefore, technological properties of wood from these species planted in their natural habitat tend to be very different when compared to wood from trees planted in exotic sites.

We explored distinct natural climatic conditions in a subtropical region to evaluate the resistance of three fast-growing Brazilian eucalypts exposed in outdoor. Color, wetting and chemical changes on the surface of three fast-growing Brazilian Eucalypts after 360 days of outdoor exposure were investigated.

\section{MATERIALS AND METHODS}

\section{Preparation of the material}

Sixty free-defect heartwood samples of Eucalyptus cloeziana (gympie messmate), Eucalyptus saligna (blue gum) and Eucalyptus grandis (rose gum) were prepared from radial section with dimensions of $140 \times 100 \times 25 \mathrm{~mm}$ (length, width and thickness). Twenty samples per species were kept in a climatic chamber at $20^{\circ} \mathrm{C}$ and $65 \%$ of relative humidity to reach the equilibrium moisture content $(\sim 12 \%)$, which was the initial point for the outdoor exposure.

\section{Outdoor exposure}

Outdoor exposure was performed in Southern Brazil (-31 $\left.{ }^{\circ} 46^{\prime} 42,1752^{\prime \prime} ;-52^{\circ} 21^{\prime} 4,6722^{\prime \prime}\right)$. The Koeppen classification of the site is Cfa (humid subtropical climate) and the altitude of approximately $7 \mathrm{~m}$ above sea. Wood samples were kept facing south and inclined at a $45^{\circ}$ angle (DIN EN 927-3:201210) for 360 days - March 2013 to March 2014. Five samples for each species were collected every 120 days. Another five samples remained in a climatic chamber (control treatment). Weather conditions (Table 1) during the exposure were collected in the meteorological data sheets published by Brazilian Agricultural Research Corporation (Embrapa Clima Temperado).

Table 1. Climatic conditions during the outdoor exposure time.

\begin{tabular}{|c|c|c|c|c|c|c|c|c|c|c|c|c|c|}
\hline & \multicolumn{13}{|c|}{ Time of exposure } \\
\hline & \multicolumn{10}{|c|}{2013} & \multicolumn{3}{|c|}{2014} \\
\hline & Mar & Apr & May & Jun & Jul & Aug & Sep & Oct & Nov & Dec & Jan & Feb & Mar \\
\hline $\mathrm{T}\left({ }^{\circ} \mathrm{C}\right)$ & 20,3 & 19,4 & 15,6 & 13,8 & 12,9 & 12,6 & 16,5 & 17,9 & 20,9 & 24,2 & 25,2 & 24,4 & 21,3 \\
\hline Rainfall (mm) & 56,2 & 150 & 91,4 & 67,2 & 52,5 & 83,5 & 145,9 & 184,1 & 119,1 & 71,8 & 217,1 & 206,9 & 173,9 \\
\hline RH (\%) & 77,8 & 79,7 & 83 & 83,1 & 82 & 82,7 & 82,7 & 82 & 81,9 & 75,1 & 79,5 & 81,1 & 77,5 \\
\hline Sunlight (h) & 399,9 & 344,4 & 217,8 & 211,2 & 226,9 & 242 & 311,7 & 451,7 & 517,7 & 608,5 & 492 & 438,2 & 393,5 \\
\hline
\end{tabular}




\section{Color evaluation}

Cracking and visual color changes of control and weathered wood samples were analyzed by highresolution optical images using a stereomicroscope Zeiss Discovery 1,0 (Carl Zeiss, Jena-Germany).

Color changes were investigated using a spectrophotometer (CM5 model, Konica Minolta) configured to D65 light source and observation angle of $10^{\circ}$ (CIE-Lab standard). Three measurements for each surface were performed in unexposed and weathered wood samples. We determined the parameters: lightness $\left(\mathrm{L}^{*}\right)$, green-red chromatic coordinate $\left(\mathrm{a}^{*}\right)$, blue-yellow chromatic coordinate $\left(\mathrm{b}^{*}\right)$, chroma $\left(\mathrm{C}^{*}\right)$, hue angle $(\mathrm{h})$ and color difference $(\Delta \mathrm{E})$. Chromaticity diagram (Konica Minolta 2007, Mattos et al. 2013) were used to investigate the relation between $\mathrm{L}^{*}$ and $\mathrm{C}^{*}$. Color parameters were analyzed by analysis of variance at $5 \%$ of probability of error. If the null hypothesis was rejected, average values were compared with Tukey Test at $5 \%$ of probability of error $(p<0,05)$.

\section{Apparent contact angle (CA)}

The effect of outdoor exposure on the wettability were investigated by the sessile drop type contact angle technique in a Krüss DSA25E goniometer. Two droplets of deionized water (surface tension of $72,80 \mathrm{mN} \mathrm{m}$-1) with $5 \mu 1$ volume were deposited on the surface of each wood sample. The apparent contact angle (CA) was measured at $5 \mathrm{~s}$ after the deposition on the sample surface. The phenomena of spreading and absorption of droplets on the wood surface were investigated by the variation of droplet volume and visual analysis.

\section{Thermogravimetric analysis (TGA)}

Changes in chemical composition of weathered samples were investigated using a Shimadzu DTG$60 \mathrm{H}$ equipment. Thermal degradation events of the main wood compounds (hemicelluloses, cellulose and lignin) were analyzed. Wood chips from the surface of each sample only with weathered wood (gray color) were cut and milled in a Knife mill (Willey type). The samples (5-10 mg) were heating from 25 to $600^{\circ} \mathrm{C}$ (gas flow of $20 \mathrm{ml} \cdot \mathrm{min}^{-1}$ ) at heating rate of $10^{\circ} \mathrm{C} / \mathrm{min}$ under inert atmosphere of $\mathrm{N}_{2}$. 


\section{RESULTS AND DISCUSSION}

\section{Color changes}

Action of weather on rose gum, blue gum and gympie messmate woods significantly changes their surface appearance (Figure 1). High-resolution images - at ten times of magnification - illustrated the wood surface grayish and the appearance of micro cracks after 120 days of exposure. Number of micro cracks increase from 240 days and remains constant up to 360 days of outdoor exposure.
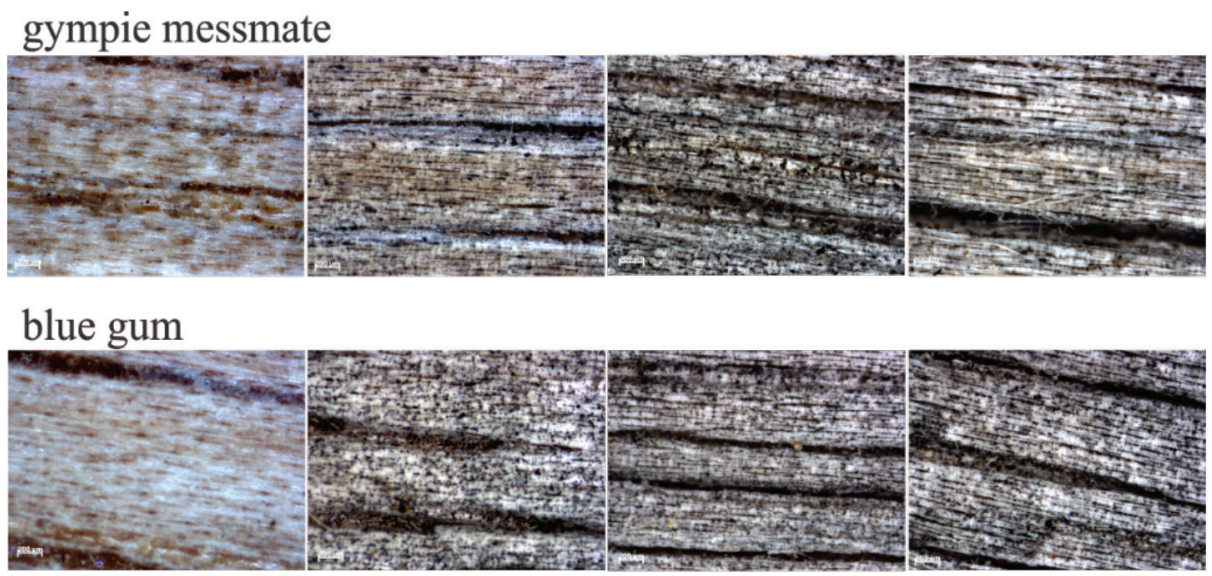

rose gum

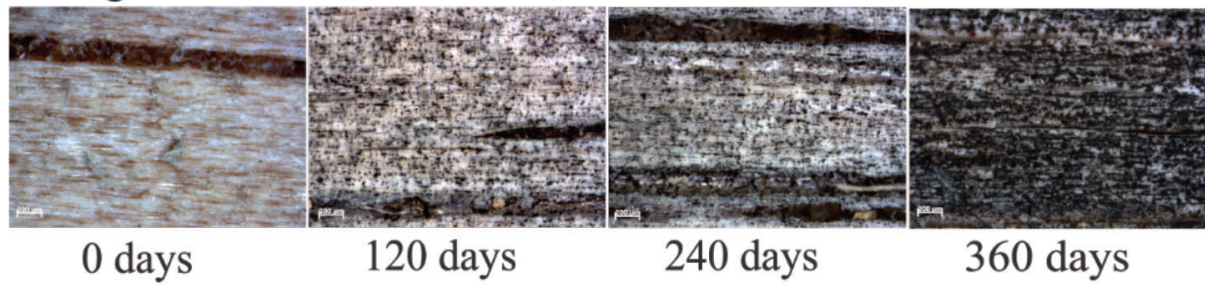

Figure 1. Light microscopic appearance of gympie messmate, blue gum and rose gum woods after 360 days of outdoor exposure.

Dark stains on the wood surface of three species were observed, indicating colonization by fungi due to the environmental conditions during the exposure - especially temperature and humidity and surface oxidation. At the end of outdoor exposure, rose gum wood presented the most darkened surface. According to Williams (2005), occurrence of cracks, warps, checking and growth of mold are characteristics of weathered wood.

Decrease of lightness parameter $\left(L^{*}\right)$ confirmed the eucalypt wood darkening as a function of outdoor exposure time (Table 2). Lightness decreased significantly in the first 120 days of exposure followed by a tendency to stabilization from 240 to 360 days. $L^{*}$ varied from 18 to $27 \%$, wherein the highest decrease occurred in the period of 0-120 days. Pfeffer et al. 2012, observed similar behavior of wood color treated with water glass, siloxane or DMDHEU (1,3-dimethylol-4,5-dihydroxyethylene urea) after outdoor exposure. The authors confirmed the most significant color changes at the first three months. 
Chromatic coordinates ( $a^{*}$ and $b^{*}$ ) were more susceptible to changes in the first 120 days of outdoor exposure (Table 2). Regarding $a^{*}$ parameter, gympie messmate wood presented lower initial value than those observed in blue gum and rose gum woods. After 360 days of exposure, $a^{*}$ was similar for all eucalypt woods. High values of $a^{*}$ are related to condensation, decomposition and/or oxidation of proanthocyanidins, lignin and other extractives in byproducts. These byproducts absorb complementary red light, contributing to the increment of red tones in wood (Chen et al. 2012). In this study, significant decrease of $\mathrm{a}^{*}$ can be attributed to changes in lignin structure, since red tones of wood surface decreased and absorption in $400 \mathrm{~cm}^{-1}$ (related to lignin) also decreased after outdoor exposure (Figure 2B, 2C and 2D). Furthermore, fungal hyphae in weathered wood can influence in $a^{*}$ parameter, since hyphae color is brown due to the presence of melanin (Zink and Fengel 1989).

Table 2. Color parameters of three eucalypt woods after 0-360 days of outdoor exposure.

\begin{tabular}{|c|c|c|c|c|}
\hline & $\begin{array}{l}\text { Exposure time } \\
\text { (days) }\end{array}$ & Gympie messmate & Blue gum & Rose gum \\
\hline \multirow{4}{*}{$L^{*}$} & 0 & $69,0(2,3)$ a & $66,1(3,4) a$ & $69,5(2,3) \mathrm{a}$ \\
\hline & 120 & $53,7(1,1) b$ & $54,0(1,5) b$ & $56,5(1,9) \mathrm{b}$ \\
\hline & 240 & $50,0(1,3) \mathrm{c}$ & $51,6(1,2) \mathrm{c}$ & $52(1,9) \mathrm{c}$ \\
\hline & 360 & $49,9(1,7) \mathrm{c}$ & $47,8(2,3) \mathrm{d}$ & $50,2(1,9) \mathrm{c}$ \\
\hline \multirow[t]{4}{*}{$a^{*}$} & 0 & $6,8(0,4) a$ & $11,7(0,8) \mathrm{a}$ & $10,6(0,7) a$ \\
\hline & 120 & $3,4(0,4) b$ & $2,6(0,3) b$ & $2,6(0,5) b$ \\
\hline & 240 & $1,7(0,2) \mathrm{c}$ & $1,7(0,3) \mathrm{c}$ & $1,6(0,2) \mathrm{c}$ \\
\hline & 360 & $1,8(0,2) \mathrm{c}$ & $1,6(0,2) \mathrm{c}$ & $1,8(0,2) \mathrm{c}$ \\
\hline \multirow{4}{*}{$b^{*}$} & 0 & $19,8(0,8) \mathrm{a}$ & $19,8(0,5) \mathrm{a}$ & $20,1(1,1) \mathrm{a}$ \\
\hline & 120 & $12,0(1,0) b$ & $7,9(0,6) b$ & $8,3(0,89) \mathrm{b}$ \\
\hline & 240 & $6,3(0,7) \mathrm{c}$ & $5,7(0,7) \mathrm{c}$ & $5,2(0,71) \mathrm{c}$ \\
\hline & 360 & $5,6(0,7) \mathrm{c}$ & $4,8(0,6) \mathrm{d}$ & $5,5(0,43) \mathrm{c}$ \\
\hline \multirow{4}{*}{$C^{*}$} & 0 & $21,0(0,8) \mathrm{a}$ & $23,0(0,8) \mathrm{a}$ & $22,7(1,2) \mathrm{a}$ \\
\hline & 120 & $12,5(1,1) b$ & $8,4(0,6) b$ & $8,7(1,0) b$ \\
\hline & 240 & $6,5(0,8) c$ & $5,9(0,8) \mathrm{c}$ & $5,5(0,7) \mathrm{c}$ \\
\hline & 360 & $5,8(0,7) \mathrm{c}$ & $5,1(0,6) d$ & $5,8(0,5) \mathrm{c}$ \\
\hline \multirow{4}{*}{$h$} & 0 & $71,0(1,2) \mathrm{a}$ & $59,5(1,6) \mathrm{a}$ & $62,3(1,0) \mathrm{a}$ \\
\hline & 120 & $74,4(0,9) \mathrm{b}$ & $72,1(0,9) \mathrm{b}$ & $73,0(1,6) b c$ \\
\hline & 240 & $74,6(0,9) \mathrm{b}$ & $73,5(0,8) \mathrm{c}$ & $73,4(1,1) \mathrm{c}$ \\
\hline & 360 & $71,8(0,9) \mathrm{a}$ & $71,1(0,8) b$ & $71,8(1,1) b$ \\
\hline \multirow{4}{*}{$\square E$} & 0 & - & - & - \\
\hline & 120 & 17,56 & 19,26 & 19,33 \\
\hline & 240 & 23,91 & 22,53 & 24,69 \\
\hline & 360 & 24,39 & 25,73 & 25,70 \\
\hline
\end{tabular}

Values between parentheses refer to standard deviation. Average values followed by the same letter in the column are not statistically different at $5 \%$ of probability of error (Tukey Test, $\mathrm{p}<0,05$ ). 
Increment of red tones and both decrement of yellow tones and chroma $\left(C^{*}\right)$ confirmed the grayish tone of weathered wood surfaces and, consequently, decrease of their purity. Grayish impression of the wood surface is influenced by the combination of whitening of the surface (lignin degradation) and darkening of the surface (colonization by fungi). Color vivacity of weathered woods surfaces decreased as a function of exposure time, especially until 120 days. The most significant variation of hue angle $(\mathrm{h})$ was in the first 120 days of exposure followed by a stabilization.

Color difference $(\Delta E)$ (Table 2) and chromaticity diagram (Figure 2A) proved the intense color changes of weathered woods. Outdoor exposure converted the pale tones of Eucalypt woods into grayish tones, which is corroborate by Tolvaj and Papp 1999.
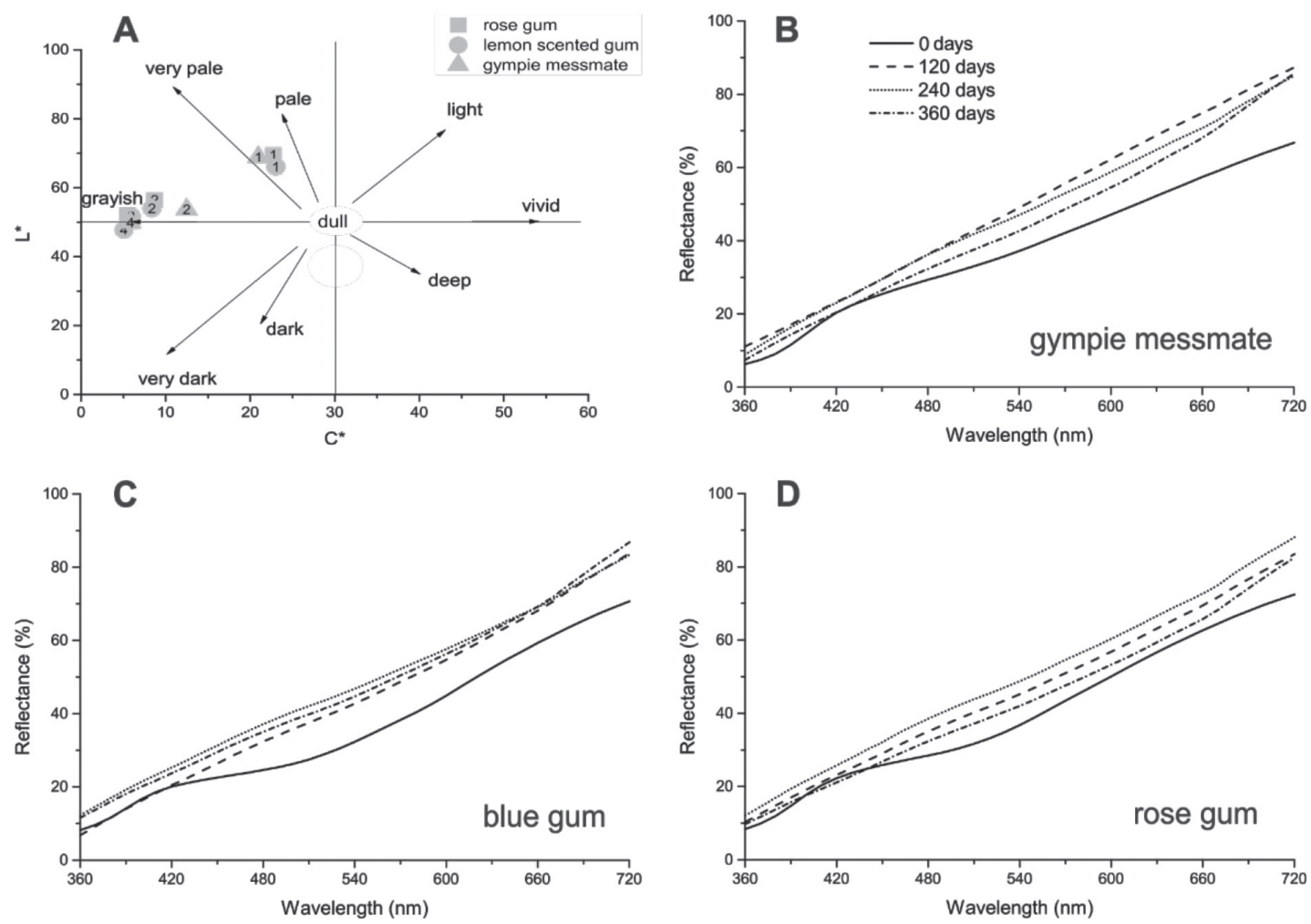

Figure 2. Chromaticity diagram $\left(L^{*} \mathrm{x} C^{*}\right)$ and reflectance curves of gympie messmate, blue gum and rose gum wood after 0-360 days of outdoor exposure.

Great level of rainfall - especially in the last six months (Sept/13 - Mar/14) -contributed significantly to improve the wood deterioration. This climatic agent removes the degradation products, such as them from lignin. Furthermore, Mattos et al. 2013, reported that significant changes in weathered wood color are related to higher degree of air relative humidity during 360 days of outdoor exposure. We observed high incidence of sunlight combined with high relative humidity of air. Even in months with higher sunlight and greater temperatures, relative humidity of air remained above $75 \%$. Discoloration of wood observed in this study is extremely undesirable due to decrement of its aesthetic value. 


\section{Chemical changes}

Thermogravimetric analysis (Figure 3) illustrated the significant changes in thermal decomposition of cell wall polymers of Eucalypt woods. Four thermal decomposition events were identified in unexposed and weathered woods.
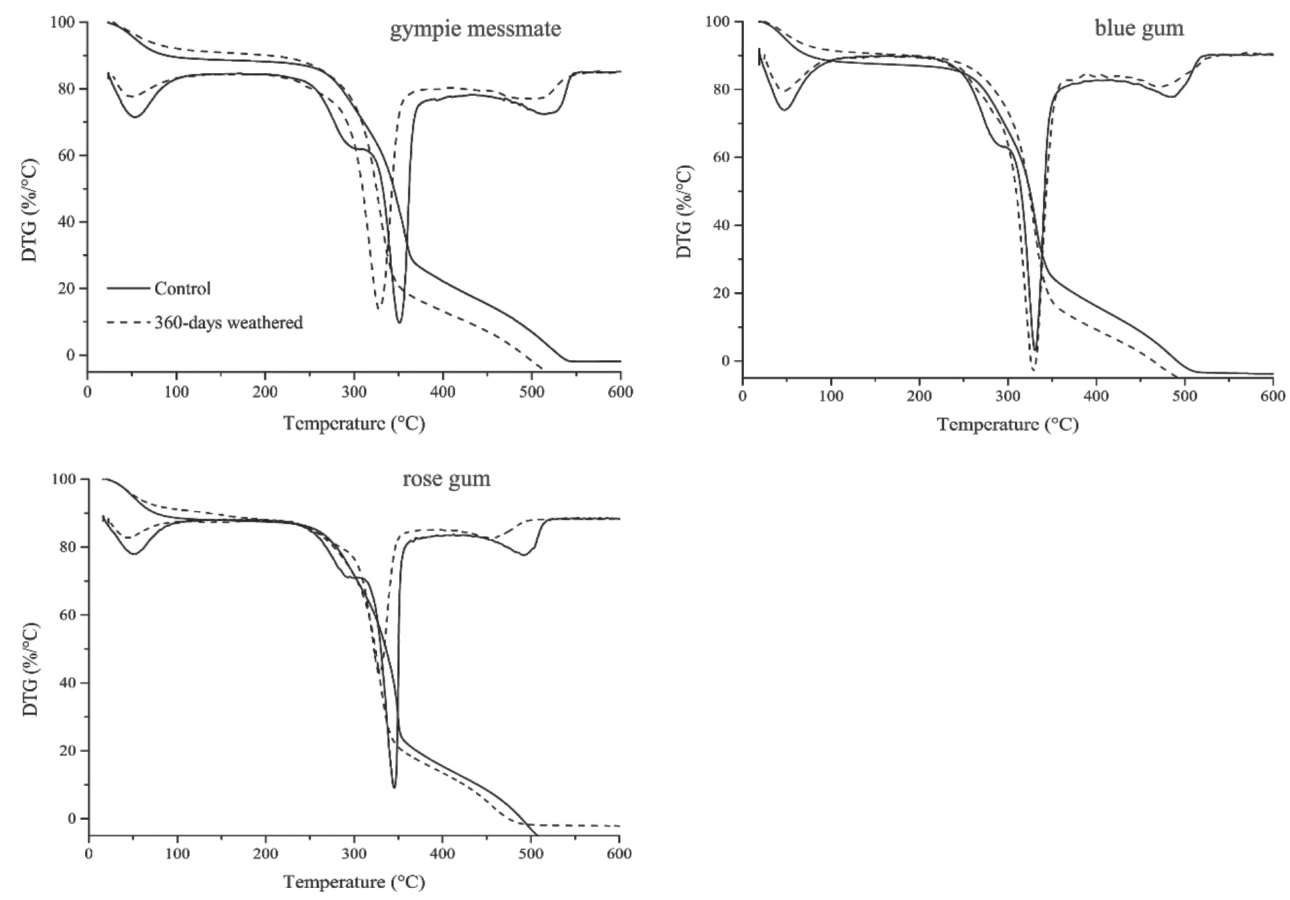

Figure 3. Thermograms (TG) and derivative thermograms (DrTG) of gympie messmate, blue gum and rose gum woods after 360 days of outdoor exposure.

First peak occurs up to $100^{\circ} \mathrm{C}$ and is related to water desorption of wood samples. We observed a shoulder from 250 to $315^{\circ} \mathrm{C}$, which illustrates thermal decomposition of hemicelluloses. This shoulder in unexposed wood is more dominant than in weathered wood, especially in rose gum and blue gum woods. The most intense peak was observed at $300-350^{\circ} \mathrm{C}$. This peak refers to thermal decomposition of crystalline cellulose. We observed a shift and changes in this peak intensity for weathered woods, which prove the action of weather in cellulose chains.

The fourth peak occurs predominantly between 450 and $550^{\circ} \mathrm{C}$ and refers to lignin thermal decomposition. Kim et al. 2006, affirmed that lignin degradation occurs at $250-500^{\circ} \mathrm{C}$, which is the same range observed in the present study. On the other hand, Yang et al. 2007, indicated slow thermal degradation of lignin between 100 and $900^{\circ} \mathrm{C}$ with weight loss $<0,14$ wt. $\% /{ }^{\circ} \mathrm{C}$. Lignin is the only compound of wood chemical structure with high absorption in ultraviolet-visible region. This compound is a key structure in wood weathering (George et al. 2005).

In summary, significant changes in thermal deterioration of hemicelluloses, cellulose and lignin of weathered woods are related to the action of climatic agents on materials' surface. According to Evans et al. 1996, outdoor exposure leads to the depolymerization of cellulose and loss of hemicelluloses and lignin contents. 


\section{Wetting parameters}

Changes in wettability of both untreated and weathered woods confirmed the surface photodegradation (Figure 4). Wettability increased as a function of time of outdoor exposure. The most significant changes in wettability was from 0 to 120 days. Great increment of apparent contact angle after 240 days of exposure resulted in a fully wettable surface, i.e., full absorption and spreading of water droplet on wood surface.
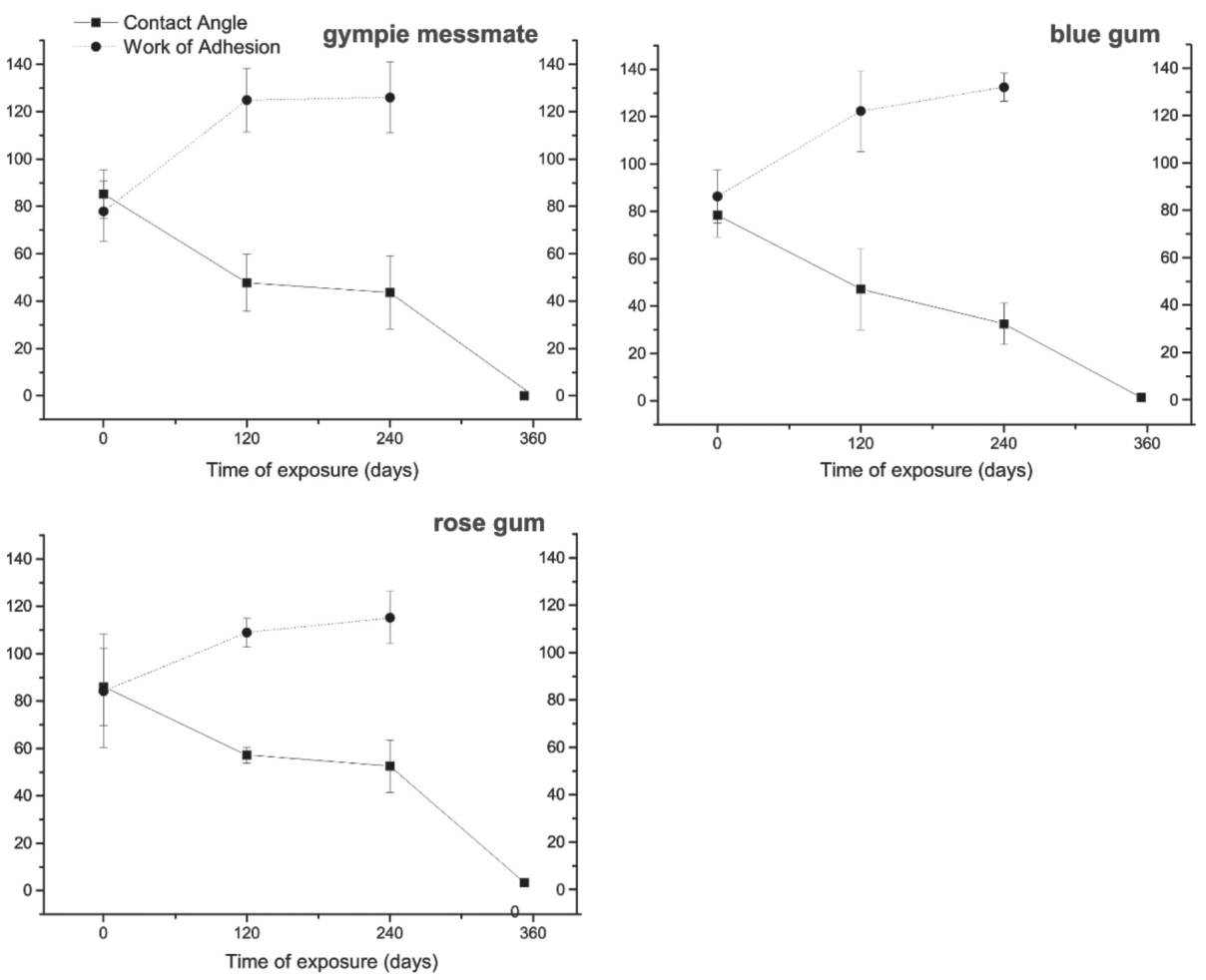

Figure 4. Kinetics of apparent contact angle and work of adhesion of gympie messmate, blue gum and rose gum woods.

In the first 120 days of outdoor exposure, rose gum was the less susceptible wood to weathering (reduction of 33\%), followed by blue gum wood (40\%) and gympie messmate wood (44\%). During the period of apparent contact angle stabilization (120-240 days), reduction of wettability was similar for rose gum and gympie messmate $(\sim 5 \%)$, while apparent contact angle of blue gum wood decreased approximately $19 \%$. After 360 days of exposure, all the eucalypt woods presented a fully wetted surface.

Work of adhesion showed an inverse behavior of apparent contact angle, since increment of wetting results in higher surface adhesion. Nevertheless, increment of both wetting and adhesion of wood surface is related to chemical changes after outdoor exposure. Lignin degradation and leaching of extractives of weathered wood surface (Rowell 2005) increased the degree of surface hydrophilicity. Furthermore, appearance of micro cracks increased the degree of wettability, since both phenomena of absorption and spreading of water droplets on the wood surface were observed. 


\section{CONCLUSIONS}

Outdoor exposure for 360 days significantly changed the degree of thermal degradation of wood macro components, color and wettability of eucalypt woods. In general, the degree of modification was similar for all species. Exposure for 120 days was sufficient to increase surface graying. Decrement of red tones was more pronounced in both blue gum and gympie messmate woods than in rose gum wood.

Very hydrophilic surface was obtained after 360 days of outdoor exposure, wherein wood surface presented both full absorption and spreading of water droplets. Appearance of micro cracks on the wood surface resulted in fully spreading of water droplets when in contact to the substrate.

\section{ACKNOWLEDGMENTS}

The authors thank to CNPq (National Counsel of Technological and Scientific Development) and CAPES (Coordination for the Improvement of Higher Level Personnel) for supporting this work.

\section{REFERENCES}

Akhtari, M.; Nicholas, D. 2014. Effect of profiling and preservative treatments on the weathering characteristics of Southern pine deck boards. Eur J Wood Prod 72(6): 829-831.

Baar, J.; Gryc, V. 2012. The analysis of tropical wood discoloration caused by simulated sunlight. Eur J Wood Prod 70(1-3): 263-269.

Baysal, E.; Degirmentepe, S.; Simsek, H. 2014. Some surface properties of thermally modified Scots Pine after artificial weathering. Maderas Ciencia y tecnología 16(4): 435-444.

Chen, Y.; Fan, Y.; Gao, J.; Stark, N.M. 2012. The effect of heat treatment on the chemical and color change of black locust (Robinia pseudocacia) wood flour. BioResources 7(1): 1157-1170.

De Windt, I.; Van den Bulcke, J.; Wuijtens, I.; Coppens, H.; Van Acker, J. 2014. Outdoor weathering performance parameters of exterior wood coating systems on tropical hardwood substrates. Eur J Wood Prod 72(2): 261-272.

Evans, P.D.; Thay, P.D.; Schmalzl, K.J. 1996. Degradation of wood surfaces during natural weathering. Effects on lignin and cellulose and on the adhesion of acrylic latex primers. Wood Sci Technol 30(6): 411-422.

Feist, W.C.; Hon, D.N.S. 1984. Chemistry of Weathering and Protection. In: R.M. Rowell (Ed.) The Chemistry of Solid Wood, Advances in Chemistry, American Chemical Society, Washington, pp. 401-451.

George, B.; Suttie, E.; Merlin, A.; Deglise, X. 2005. Photodegradation and photostabilisation of wood - the state of the art. Polymer Degradation and Stability 88 (2): 268-274.

Grüll, G.; Tscherne, F.; Spitaler, I.; Forsthuber, B. 2014. Comparison of wood coating durability in natural weathering and artificial weathering using fluorescent UV-lamps and water. Eur J Wood Prod 72(3): 367-376. 
Hon, D. 2001. Weathering and photochemistry of wood. In: D. Hon, N. Shiraishi (Eds.) Wood and Cellulosic Chemistry, Marcel Dekker, New York, pp. 513-546.

Kim, H.S.; Kim, S.; Kim, H.J.; Yang, H.S. 2006. Thermal properties of bio-flour-filled polyolefin composites with different compatibilizing agent type and content. Thermochimica Acta 451(1-2): 181-188.

Mattos, B.D.; Cademartori, P.H.G.d.; Lourençon, T.V.; Gatto, D.A. 2014. Colour changes of Brazilian eucalypts wood by natural weathering. International Wood Products Journal 5(1): 33-38.

Konica Minolta Inc. 2007. Precise color communication: Color control from perception to instrumentation. $59 \mathrm{p}$.

Missio, A.L.; Mattos, B.D.; Gatto, D.A.; Lima, E.A. 2013. Thermal Analysis of Charcoal from Fast-Growing Eucalypt Wood: Influence of Raw Material Moisture Content. Journal of Wood Chemistry and Technology 34(3): 191-201.

Pfeffer, A.; Mai, C.; Militz, H. 2012. Weathering characteristics of wood treated with water glass, siloxane or DMDHEU. Eur J Wood Prod 70(1-3): 165-176.

Rosu, D.; Teaca, C.A.; Bodirlau, R.; Rosu, L. 2010. FTIR and color change of the modified wood as a result of artificial light irradiation. Journal of Photochemistry and Photobiology B: Biology 99(3): 144-149.

Rowell, R.M. 2005. Handbook of Wood Chemistry and Wood Composites. 1 ed. CRC Press.

Tolvaj, L.; Papp, G. 1999. Outdoor weathering of impregnated and steamed black locust. International Conference on the Development of Wood Science, Wood Technology and Forestry, High Wycombe (England). Forest Products Research Centre, Buckinghamshire Chilterns University College, pp. 112-115.

Valverde, J.C.; Moya, R. 2010. Efectos de la intemperie en el color de dos acabados

Aplicados en madera de Cedrela odorata y Carapa Guianensis. Maderas Ciencia y tecnología 12(3): 171-180.

Williams, R.S. 2005. Weathering of wood. In: R.M. Rowell (Ed.) Handbook of wood chemistry and wood composites, CRC Press.

Yang, H.; Yan, R.; Chen, H.; Lee, D.H.; .Zheng, C. 2007. Characteristics of hemicellulose, cellulose and lignin pyrolysis. Fuel 86(12-13): 1781-1788.

Zink, P.; Fengel, D. 1989. Studies on the coloring matter of blue-stain fungi. Holzforschung 43(6): 371-374. 